\title{
UJI BERBAGAI VARIETAS PADI GOGO (Oriza sativa L.) DAN PENAMBAHAN BIOCHAR KULIT KAKAO PADA KETINGGIAN MENENGAH KABUPATEN MAMUJU
}

\author{
Harli A. Karim ${ }^{1)}$, Iinnaninengseh ${ }^{2)}$, Muh. Sahir ${ }^{3)}$, Zulkifli Basri ${ }^{4)}$ \\ ${ }^{1,2,3}$ Program Studi Agroteknologi, Universitas Al Asyariah Mandar \\ ${ }^{4}$ Program Studi Agribisnis, Universitas Al Asyariah Mandar \\ Jl. Budi Utomo No. Manding, Polewali Mandar \\ Korespondensi: harlipertanian@gmail.com
}

\begin{abstract}
ABSTRAK
Padi (Oryza sativa L.) merupakan komoditas tanaman pangan yang penting di Indonesia luas panen padi gogo masih sangat kecil yakni seluas 6.898 ha atau baru mencapai 3,17 \% dari luas panen padi sawah yang mencapai 217.428 ha. Salah satu faktor yang berpengaruh terhadap produksi tanaman padi adalah kesuburan tanah. Penelitian ini menggunakan Rancangan Acak kelompok terdiri dari dua faktor yaitu: Faktor 1, beberapa varietas padi gogo terdiri dari 4 varietas yaitu :Impago 7, Impago 10, Situbagendit, dan Varietas Lokal. Sedangkan Faktor faktor 2 pemberian Biochar dari kulit buah kakao tiga taraf yaitu: 0, Biochar 200 gram, dan Biochar 400 gram. Hasil penelitian menunjukkan interaksi antara berbagai varietas padi gogo dengan Biochar kulit kakao tidak memberikan pengaruh nyata pada semua parameter yang diamati. Varietas Situ Bagendit memberikan pengaruh baik pada parameter tinggi tanaman umur 4 MST, begitu pula dengan Varietas local memberikan pengaruh baik pada parameter tinggi tanaman umur 8 MST. Pemberian Biochar 400 gram/bedengan memberikan pengaruh baik pada parameter jumlah daun umur 4 dan 8 MST, jumlah anakan dan berat 1000 bulir gabah dan. Sedangkan dosis Biochar 200 gram/bedengan juga memberikan pengaruh baik pada parameter tinggi tanaman umur 4 MST, hasil biomassa dan Rata-Rata Produktivitas dalam ton/ha.
\end{abstract}

Kata Kunci : produksi, produktifitas, padi gogo, biochar, lahan kering

\begin{abstract}
Rice (Oryza sativa L.) is an important food crop commodity in Indonesia, the harvest area for upland rice is still very small, namely an area of 6,898 ha or only $3.17 \%$ of the harvested area for lowland rice which reaches 217,428 ha. One of the factors that influence rice production is soil fertility. This study used a randomized block design consisting of two factors, namely: the first factor was several upland rice varieties consisting of 4 varieties, namely: Impago 7, Impago 10, Situbagendit, and Local Varieties, while the second factor was the provision of Biochar from three levels of cocoa pod skin, namely : 0, Biochar 200 grams, and Biochar 400 grams. The results showed that the interaction between various upland rice varieties and cocoa husk Biochar did not have a significant effect on all observed parameters. Situ Bagendit varieties have a good effect on plant height parameters at $4 \mathrm{WAP}$, as well as local varieties have a good effect on plant height parameters at $8 \mathrm{WAP}$. Application of Biochar $400 \mathrm{gram} / \mathrm{beds}$ gave a good effect on the parameters of the number of leaves aged 4 and 8 WAP, number of tillers and weight of 1000 grains of grain and. Meanwhile, the Biochar dosage of 200 grams/beds also had a good effect on the parameters of plant height at $4 \mathrm{WAP}$, biomass yield and average productivity in tonnes/ha.
\end{abstract}

Keywords : production, productivity, upland rice, biochar, dry land 


\section{PENDAHULUAN}

Padi (Oryza sativa L.) merupakan komoditas tanaman pangan yang penting di Indonesia.Penduduk Indonesia menjadikan beras sebagai bahan makanan pokok. 95\% penduduk Indonesia mengkonsumsi bahan makanan ini. Beras mampu mencukupi $63 \%$ total kecukupan energi dan $37 \%$ protein. Kandungan gizi dari beras tersebut menjadikan komoditas padi sangat penting untuk kebutuhan pangan sehingga menjadi perhatian di Indonesia untuk memenuhi kebutuhan beras (Norsalis, 2011; Ellya Ekaristi Taringan, 2013)

Kebutuhan beras sebagai salah satu sumber pangan utama penduduk Indonesia terus meningkat.Pertambahan penduduk yang terus bertambah dengan laju peningkatan sekitar $2 \%$ per tahun, juga adanya perubahan pola konsumsi penduduk dari non beras ke beras maka kebutuhan beras juga bertambah. Pada pihak lain terjadinya penciutan lahan sawah irigasi subur (intensif) akibat konservasi lahan untuk kepentingan non pertanian dan munculnya fenomena degradasi kesuburan lahan menyebabkan produktivitas padi sawah irigasi cenderung melandai (Leveling off). Berkaitan dengan prakiraan terjadinya penurunan produksi tersebut maka perlu diupayakan penanggulangannya melalui peningkatan produktivitas lahan sawah yang ada, pencetakan lahan irigasi baru dan pengembangan lahan potensial lainnya termasuk di dalamnya lahan kering (Suriansyah et al., 2013).

Tanaman padi dapat dibedakan dalam dua tipe, yaitu padi kering yang tumbuh di lahan kering dan padi sawah yang memerlukan air menggenang dalam pertumbuhan dan perkembangannya.Padi ladang merupakan tanaman padi yang ditanam baik pada lahan kering yang datar maupun lahan kering berlereng tanpa galengan dimana pengolahan lahan dan tanam pada kondisi kering serta pertumbuhan dan produksinya sangat tergantung pada ketersediaan curah hujan yang mempengaruhi kelembaban tanah (Suci Rodian Noer, 2017).

Di banyak daerah potensi lahan kering belum dimanfaatkan secara optimal bagi pengembangan tanaman padi dan tanaman pangan lainnya. Proporsi luas panen padi gogo masih sangat kecil yakni seluas 6.898 ha atau baru mencapai 3,17 \% dari luas panen padi sawah yang mencapai 217.428 ha (BPS, 2014). Produksi padi di Indonesia yang dikonversikan dari Gabah Kering Giling (GKG) menjadi beras tahun 2014 mencapai 44,44 juta ton mengalami peningkatan di tahun 2015 sebesar 2,86 juta ton, dengan jumlah produksi tahun 2015 sebesar 
47,30 juta ton. Kenaikan poduksi padi tahun 2015 disebabkan adanya peningkatan luas panen sebesar 319,331 hektar (BPS Nasional, 2015)

Tingkat konsumsi beras di Indonesia tahun 2015 sebesar 30,9 juta ton/tahun. Secara absolut terdapat pola konsumsi beras di tingkat rumah tangga cenderung terus mengalami penurunan antara tahun 2001 hingga tahun 2015 maupun rata-rata kondisi 5 tahun terakhir. Adanya penurunan konsumsi beras secara langsung ini diduga adanya peningkatan kesejahteraan masyarakat dan kesadaran tentang kesehatan sehingga mengalihkan konsumsi karbohidrat yang berasal dari beras dengan makanan pengganti beras yang lebih sehat. Sulawesi Barat merupakan salah satu daerah penghasil komoditas pangan yang besar di kawasan Timur Indonesia. Komoditas tanaman pangan yang dihasilkan Sulawesi barat salah satunya adalah tanaman pangan yang dibudidayakan dilahan kering atau jenis tanaman padi ladang dengan rata-rata Jumlah produksi padi ladang pada tahun 2017 yaitu sekitar 56,901 (BPS, 2018).

Selain permasalahan yang telah di kemukakan sebelumnya, faktor kesuburan tanah juga berpengaruh terhadap produksi tanaman padi. Pemupukan secara anorganik secara terus menerus dan berlebihan akan menyebabkan penurunan unsur hara. Pemberian pupuk yang tepat dan seimbang pada tanaman khususnya padi akan menurunkan biaya pemupukan, takaran pupuk juga lebih rendah, hasil padi relativ sama, tanaman lebih sehat, mengurangi hara yang terlarut dalam air, dan menekan unsur yang berbahaya terbawa dalam makanan (Partohardjono, 1999 ; Ade Alavan et al., 2015).

Saat ini telah mulai berkembang penggunaan biochar/arang limbah pertanian sebagai bahan pembenah tanah alternatif.Biochar mampu bertahan lama di dalam tanah atau mempunyai efek yang relatif lama (Fraser, 2010 dalam N.L. Nurinda et al.,2017), atau relatif resisten terhadap serangan mikroorganisme, sehingga proses dekomposisinya berjalan lamban (Tang et al., 2013. Dalam N.L. Nurinda et al., 2017). Biochar limbah pertanian merupakan hasil konversi limbah pertanian melalui proses pembakaran tidak sempurna dengan oksigen terbatas. Biochar juga terbukti efektif dalam meningkatkan $\mathrm{pH}$ dan sekaligus menurunkan kemasaman tanah khususnya pada lahan kering masam yang banyak ditemui pada lahan pertanian di Indonesia (Nurida et al., 2013; Nurida 2014; Nurida et al., 2015; Zhu et al., 2014. Dalam N.L. Nurinda, et al., 2017).

\section{BAHAN DAN METODE}

Penelitian dilaksanakan di Kecamatan Tapalang Kabupaten Mamuju Sulawesi Barat (ketinggian $400 \mathrm{mdpl}$ ). Metode yang digunakan dalam penelitian ini adalah berdasarkan 
Rancangan Acak Kelompok (RAK) yang disusun dalam bentuk Faktorial terdiri dari 2 faktor. Berbagai varietas ditempatkan sebagai faktor pertama yaitu terdiri dari : G1 = varietas Inpago 7, G2 = varietas Inpago 10, G3 = Situ Bagendit, G4 = varietas local. Kemudian perlakuan pemberian beberapa gram Biochar kulit kakao (K) ditempatkan sebagai faktor kedua yaitu terdiri dari : K0 = Perlakuan tanpa pemberian Biochar (Kontrol), K1 = Perlakuan pemberian Biochart 200 gram/bedengan, K2 = perlakuan pemberian Biochart 400 gram/ bedengan. Setiap pelakuan masing-masing di ulang sebanyak 3 (tiga) ulangan sehingga terdapat 36 unit penelitian, di mana setiap unit terdapat 4 tanaman sehingga jumlah tanaman yang di gunakan sebanyak 144 tanaman.

\section{HASIL DAN PEMBAHASAN}

\section{Tinggi tanaman}

Hasil Uji Beda Nyata Terkecil taraf 0,01 pada Tabel 1, memperlihatkan bahwa varietas Situ Bagendit (G3) memberikan pengaruh lebih baik dan berbeda sangat nyata dibanding varietas lain, namun tidak berbeda dengan varietas local (G4), begitu pula dengan pemberian Biochar 200 gram/bedengan (K1) juga memberikan pengaruh lebih baik dan berbeda sangat nyata dibanding dengan tanpa perlakuan (K0), tetapi tidak berbeda dengan pemberian Biochar 400 gram/bedengan (K2) pada parameter tinggi tanaman umur 4 minggu setelah tanam.

Tabel 1. : Rata-Rata Tinggi Tanaman (cm) Umur 4 MST Tanaman Padi Gogo

\begin{tabular}{cccccc}
\hline & \multicolumn{3}{c}{$\begin{array}{c}\text { Biochar Kulit Kakao } \\
\text { (gr/petak) }\end{array}$} \\
\cline { 2 - 4 } Parietas & $\begin{array}{c}\text { K0 } \\
\text { Padi Gogo }\end{array}$ & $\begin{array}{c}\text { K1 } \\
(200)\end{array}$ & $\begin{array}{c}\text { K2 } \\
(400)\end{array}$ & Rata-Rata & $\begin{array}{c}\text { NP. BNT } \\
\alpha 0,01\end{array}$ \\
\hline G1 (Impago 7) & 42.86 & 45.01 & 45.91 & $44.59^{\mathrm{a}}$ & 2.07 \\
G2 (Impago 10) & 43.14 & 47.70 & 46.35 & $45.73^{\mathrm{a}}$ & \\
G3 (Situ Bagendit) & 47.67 & 47.76 & 48.47 & $47.96^{\mathrm{b}}$ & \\
G4 (Varietas Lokal) & 46.01 & 48.50 & 49.08 & $47.86^{\mathrm{b}}$ & \\
\hline Rata-Rata & $44.92^{\mathrm{a}}$ & $47.24^{\mathrm{b}}$ & $47.45^{\mathrm{b}}$ & &
\end{tabular}

Keterangan : Angka-angka yang diikuti oleh huruf yang tidak sama berarti berbeda nyata pada Uji BNT Taraf $\alpha 0,01$

Hal itu diduga pada umur tersebut merupakan fase dimana proses pembelahan dan pembesaran sel. Kedua proses ini dipengaruhi oleh turgor sel. Proses pembelahan dan pembesaran sel akan terjadi apabila sel mengalami turgiditas yang unsur utamanya adalah ketersediaan air, dimana ketersediaan air dalam tanah sangat berkaitan dengan kandungan 
bahan organik dalam tanah, sehingga penambahan biochart sebagai pengganti pupuk dapat menambah kandungan hara serta mampu memperbaiki sifat fisik, kimia, dan biologis tanah. Tinggi tanaman merupakan ukuran pertumbuhan tanaman yang dapat dilihat dari pertambahan ukuran tanaman.Hal ini diawali dari perbanyakan atau pembelahan sel. Pembesaran dan pembelahan sel hanya dapat terjadi pada tingkat turgiditas sel yang tinggi.

Hasil Uji Beda Nyata Terkecil taraf 0,01 pada Tabel 2, memperlihatkan bahwa varietas lokal (G4) memberikan pengaruh lebih baik dan berbeda sangat nyata dibanding varietas lain pada parameter tinggi tanaman umur 8 minggu setelah tanam.

Tabel 2. : Rata-Rata Tinggi Tanaman (cm) Umur 8 MST Tanaman Padi Gogo

\begin{tabular}{|c|c|c|c|c|c|}
\hline \multirow{2}{*}{$\begin{array}{l}\text { Varietas } \\
\text { Padi Gogo }\end{array}$} & \multicolumn{3}{|c|}{$\begin{array}{c}\text { Biochar Kulit Kakao } \\
\text { (gr/petak) }\end{array}$} & \multirow{2}{*}{ Rata-Rata } & \multirow{2}{*}{$\begin{array}{c}\text { NP. BNT } \\
\alpha 0,01\end{array}$} \\
\hline & $\begin{array}{l}\text { K0 } \\
(0)\end{array}$ & $\begin{array}{c}\mathrm{K} 1 \\
(200)\end{array}$ & $\begin{array}{c}\mathrm{K} 2 \\
(400)\end{array}$ & & \\
\hline G1 (Impago 7) & 74.84 & 77.27 & 81.22 & $77.77^{\mathrm{a}}$ & 9.44 \\
\hline G2 (Impago 10) & 73.97 & 81.15 & 79.64 & $78.25^{\mathrm{a}}$ & \\
\hline G3 (Situ Bagendit) & 81.83 & 84.50 & 83.50 & $83.27^{\mathrm{a}}$ & \\
\hline G4 (Varietas Lokal) & 86.28 & 88.50 & 87.17 & $87.31^{\mathrm{b}}$ & \\
\hline Rata-Rata & 79.22 & 82.84 & 82.86 & & \\
\hline
\end{tabular}

Keterangan : Angka-angka yang diikuti oleh huruf yang tidak sama berarti berbeda nyata pada Uji BNT Taraf $\alpha 0,01$

Diduga hal itu dikarenakan karena pertumbuhan antara satu kultivar yang terdapat di masing-masing varietas dengan kultivar lainnya tidak seragam yang dipengaruhi oleh perbedaan genetik yang mengakibatkan setiap kultivar memiliki ciri dan sifat khusus. Perbedaan susunan genetik merupakan salah satu faktor penyebab keragaman penampilan tanaman, dalam hal ini tinggi tanaman.Perbedaan tinggi tanaman lebih ditentukan oleh faktor genetik, di samping dipengaruhi oleh kondisi lingkungan tumbuh tanaman.Apabila lingkungan tumbuh sesuai bagi pertumbuhan tanaman, maka dapat meningkatkan produksi tanaman. Keadaan yang bervariasi dari suatu tempat ke tempat lain dan kebutuhan tanaman akan keadaan lingkungan yang khusus akan mengakibatkan keragaman pertumbuhan tanaman. Menurut Santoso dalam Ferdian Suete (2017), ada beberapa parameter yang dapat dilihat apabila tanaman membutuhkan air antara lain tinggi tanaman. Tanaman yang mengalami kekurangan kebutuhan air pertumbuhan tingginya terhambat sehingga tanaman menjadi kerdil. Namun tanaman yang mengalami kebutuhan air yang tercukupi maka pertumbuhan tinggi akan meningkat. 


\section{Jumlah Daun}

Hasil Uji Beda Nyata Terkecil taraf 0,01 pada Tabel 3, memperlihatkan bahwa pemberian Biochar 400 gram/bedengan (K2) memberikan pengaruh lebih baik dan berbeda sangat nyata dibanding dengan perlakuan lain pada parameter jumlah daun umur 4 minggu setelah tanam.

Tabel 3. : Rata-Rata Jumlah Daun Umur 4 MST Tanaman Padi Gogo

\begin{tabular}{|c|c|c|c|c|c|}
\hline \multirow{2}{*}{$\begin{array}{l}\text { Varietas } \\
\text { Padi Gogo }\end{array}$} & \multicolumn{3}{|c|}{$\begin{array}{c}\text { Biochar Kulit Kakao } \\
\text { (gr/petak) }\end{array}$} & \multirow{2}{*}{ Rata-Rata } & \multirow{2}{*}{$\begin{array}{c}\text { NP. BNT } \\
\alpha 0,01\end{array}$} \\
\hline & $\begin{array}{l}\text { K0 } \\
(0)\end{array}$ & $\begin{array}{l}\mathrm{K} 1 \\
(200)\end{array}$ & $\begin{array}{c}\mathrm{K} 2 \\
(400)\end{array}$ & & \\
\hline G1 (Impago 7) & 6.00 & 7.00 & 8.33 & 7.11 & 2.09 \\
\hline G2 (Impago 10) & 5.67 & 7.00 & 8.00 & 6.88 & \\
\hline G3 (Situ Bagendit) & 5.67 & 5.67 & 8.67 & 6.66 & \\
\hline G4 (Varietas Lokal) & 5.33 & 6.67 & 8.00 & 7.00 & \\
\hline Rata-Rata & $5.92^{\mathrm{a}}$ & $6.58^{\mathrm{a}}$ & $8.25^{\mathrm{b}}$ & & \\
\hline
\end{tabular}

Keterangan : Angka-angka yang diikuti oleh huruf yang tidak sama berarti berbeda nyata pada Uji BNT Taraf $\alpha 0,01$

Penambahan bahan organik berupa Biochart kedalam tanah diduga mampu menambah unsur hara dan menjaga ketersediaan air karena jumlah daun pada suatu tanaman berkaitan dengan proses fotosintesanya. Menurut Lakitan dalam James Manurung dkk, (2017) menyatakan bahwa perubahan fase vegetatif menjadi fase generatif merupakan perubahan yang sangat besar, karena struktur jaringannya yang berbbeda sama sekali. Perubahan besar ini merupakan cerminan dari pemacu kelompok gen-gen tertentu yang berperan dalam pembentukan bunga dan menghambat gen-gen lainnya yang berkembang dalam organ vegetatif.

Hasil Uji Beda Nyata Terkecil taraf 0,01 pada Tabel 4, memperlihatkan bahwa pemberian Biochar 400 gram/bedengan (K2) memberikan pengaruh lebih baik dan berbeda sangat nyata dibanding dengan perlakuan lain pada parameter jumlah daun umur 8 minggu setelah tanam.pemberian Biochar 400 gram/bedengan (K2)memberikan pengaruh baik di bandingkan dengan perlakuan lainnya pada jumlah daun umur 8 minggu setelah tanam. 
Tabel 4 : Rata-Rata Jumlah Daun Umur 8 MST Tanaman Padi Gogo

\begin{tabular}{|c|c|c|c|c|c|}
\hline \multirow{2}{*}{$\begin{array}{l}\text { Varietas } \\
\text { Padi Gogo }\end{array}$} & \multicolumn{3}{|c|}{$\begin{array}{c}\text { Biochar Kulit Kakao } \\
\text { (gr/petak) }\end{array}$} & \multirow{2}{*}{ Rata-Rata } & \multirow{2}{*}{$\begin{array}{c}\text { NP. BNT } \\
\alpha 0,01\end{array}$} \\
\hline & $\begin{array}{l}\text { K0 } \\
(0)\end{array}$ & $\begin{array}{l}\text { K1 } \\
(200)\end{array}$ & $\begin{array}{c}\mathrm{K} 2 \\
(400)\end{array}$ & & \\
\hline G1 (Impago 7) & 24.00 & 25.00 & 27.00 & 25.33 & 22.30 \\
\hline G2 (Impago 10) & 24.33 & 25.00 & 27.33 & 25.55 & \\
\hline G3 (Situ Bagendit) & 23.67 & 23.67 & 27.00 & 24.77 & \\
\hline G4 (Varietas Lokal) & 24.33 & 24.67 & 26.33 & 25.11 & \\
\hline Rata-Rata & $24.08^{\mathrm{a}}$ & $24.58^{\mathrm{a}}$ & $26.91^{b}$ & & \\
\hline
\end{tabular}

Keterangan : Angka-angka yang diikuti oleh huruf yang tidak sama berarti berbeda nyata pada Uji BNT Taraf $\alpha 0,01$

Pemberian Biochar terutama yang berkaitan dengan perbedaan kesuburan tanah yang dihasilkan baik secara fisik, kimia maupun biologi, akibat perbedaan dosis pada umur tertentu yang diberikan ke media tanah mengakibatkan tanaman akan tumbuh dan berkembang sesuai dengan kondisi kesuburan tanah yang ada sehinnga ketersediaan unsur hara berupa N, P, dan $\mathrm{K}$ bisa terpenuhi didalam tanah. Sebagaimana dijelaskan oleh Sutejo dalam Haris Kriswantoro dkk (2016) fungsi $\mathrm{N}$ untuk tanaman sayuran yaitu sebagai penyusun protein, untuk pertumbuhan pucuk tanaman dan menyuburkan pertumbuhan vegetatif. Fungsi P sebagai salah satu unsur penyusun protein, dibutuhkan untuk pembentukan bunga, buah dan biji, merangsang pertumbuhan akar menjadi memanjang dan tumbuh kuat sehingga tanaman akan tahan kekeringan

\section{Berat Biomassa}

Tabel 5 : Rata-Rata Berat Biomassa Tanaman Padi Gogo

\begin{tabular}{|c|c|c|c|c|c|}
\hline \multirow{2}{*}{$\begin{array}{l}\text { Varietas } \\
\text { Padi Gogo }\end{array}$} & \multicolumn{3}{|c|}{$\begin{array}{c}\text { Biochar Kulit Kakao } \\
\text { (gr/petak) }\end{array}$} & \multirow[b]{2}{*}{ Rata-Rata } & \multirow{2}{*}{$\begin{array}{c}\text { NP. BNT } \\
\alpha 0,01\end{array}$} \\
\hline & $\begin{array}{l}\text { K0 } \\
(0)\end{array}$ & $\begin{array}{l}\mathrm{K} 1 \\
(200)\end{array}$ & $\begin{array}{c}\mathrm{K} 2 \\
(400)\end{array}$ & & \\
\hline G1 (Impago 7) & 205.95 & 267.32 & 258.67 & 243.97 & 49.66 \\
\hline G2 (Impago 10) & 231.67 & 268.87 & 246.54 & 249.36 & \\
\hline G3 (Situ Bagendit) & 203.54 & 281.82 & 253.41 & 246.25 & \\
\hline G4 (Varietas Lokal) & 214.69 & 250.78 & 254.08 & 239.84 & \\
\hline Rata-Rata & $213.96^{\mathrm{a}}$ & $267.46^{b}$ & $253.17^{\mathrm{a}}$ & & \\
\hline
\end{tabular}

Keterangan : Angka-angka yang diikuti oleh huruf yang tidak sama berarti berbeda nyata pada Uji BNT Taraf $\alpha 0,01$ 
Hasil Uji Beda Nyata Terkecil taraf 0,01 pada Tabel 6, memperlihatkan bahwa pemberian Biochart Biochar 200 gram/bedengan (K1) memberikan pengaruh lebih baik dan berbeda sangat nyata dibanding dengan perlakuan lain pada parameter hasil biomassa.hal tersebut diduga karena pemberian biochar ini kedalam tanah mampu menambah ketersediaan unsur hara bagi tanaman, tersedianya air dan kurangnya penguapan maka translokasi unsur hara Nitrogen, Kalium, dan Posfor ke tanaman dapat berlangsung dengan baik, sehingga berpengaruh positif dalam proses penambahan bobot massa (gabah dan jerami). Selain ketersediaan air dan unsur hara dalam tanah, faktor lingkungan lainnya berupa cahaya juga sangat mempengaruhi berat gabah, seperti yang telah di kemukakan oleh Diptaningsari dalam James Manurung dkk, (2017) bahwa faktor lingkungan seperti cahaya sangat berperan terhadap berat gabah, sehingga cahaya yang tidak optimal menyebabkan fenotipe yang ditampilkan tidak optimal.

\section{Berat 1000 Bulir Gabah (gram)}

Hasil Uji Beda Nyata Terkecil taraf 0,01 pada Tabel 6, memperlihatkan bahwa pemberian Biochar 400 gram/bedengan (K2) memberikan pengaruh lebih baik dan berbeda sangat nyata dibanding dengan perlakuan lain pada parameter berat 1000 bulir.

Tabel 6 : Rata-Rata . Berat 1000 Bulir Gabah (gram) Tanaman Padi Gogo

\begin{tabular}{|c|c|c|c|c|c|}
\hline \multirow{2}{*}{$\begin{array}{l}\text { Varietas } \\
\text { Padi Gogo }\end{array}$} & \multicolumn{3}{|c|}{$\begin{array}{c}\text { Biochar Kulit Kakao } \\
\text { (gr/petak) }\end{array}$} & \multirow{2}{*}{ Rata-Rata } & \multirow{2}{*}{$\begin{array}{c}\text { NP. BNT } \\
\alpha 0,01\end{array}$} \\
\hline & $\begin{array}{l}\text { K0 } \\
(0)\end{array}$ & $\begin{array}{c}\mathrm{K} 1 \\
(200)\end{array}$ & $\begin{array}{c}\mathrm{K} 2 \\
(400)\end{array}$ & & \\
\hline G1 (Impago 7) & 26.83 & 29.33 & 35.42 & 30.53 & 6.40 \\
\hline G2 (Impago 10) & 26.14 & 31.50 & 34.50 & 30.71 & \\
\hline G3 (Situ Bagendit) & 26.42 & 31.97 & 33.97 & 30.78 & \\
\hline G4 (Varietas Lokal) & 27.42 & 32.81 & 35.14 & 31.78 & \\
\hline Rata-Rata & $26.70^{\mathrm{a}}$ & $31.40^{\mathrm{a}}$ & $34.75^{\mathrm{b}}$ & & \\
\hline
\end{tabular}

Keterangan : Angka-angka yang diikuti oleh huruf yang tidak sama berarti berbeda nyata pada Uji BNT Taraf $\alpha 0,01$

Hasil pada Tebel 5 diduga karena dipengaruhi oleh adanya ketersediaan air dalam tanah. Sejalan dengan Ismail dalam penelitian James Manurung dkk, (2017) melaporkan bahwa bobot 1000 butir gabah berkorelasi dengan curah hujan dan kadar air tanah. Perbedaan berat 1.000 butir biji pada setiap perlakuan menunjukkan adanya perbedaan pengisian biji karena perbedaan pasokan asimilat ke biji oleh kondisi kekuatan sink dan source. Hal ini dapat terjadi 
karena source/sumber fotosintat tanaman yang kekurangan atau cekaman air akan lebih sedikit dibandingkan dengan yang tidak mendapat cekaman. Air yang cukup akan mempengaruhi proses fotosintesis tanaman yang berimbas pada banyaknya fotosintat yang dihasilkan.

\section{Produktivitas (ton/ha)}

Hasil Uji Beda Nyata Terkecil taraf 0,01 pada Tabel 6, memperlihatkan bahwa pemberian Biochar 200 gram/bedengan (K1) memberikan pengaruh lebih baik dan berbeda sangat nyata dibanding dengan tanpa perlakuan (K0), namun tidak berbeda dengan pemberian Biochar 400 gram/bedengan (K2) pada Rata-Rata Produktivitas ton/ha.

Tabel 6 : Rata-Rata Produktivitas (ton/ha) Tanaman Padi Gogo

\begin{tabular}{cccccc}
\hline & \multicolumn{3}{c}{$\begin{array}{c}\text { Biochar Kulit Kakao } \\
\text { (gr/petak) }\end{array}$} \\
\cline { 2 - 4 } Padi Gogo & $\begin{array}{c}\text { K0 } \\
(0)\end{array}$ & $\begin{array}{c}\text { K1 } \\
(200)\end{array}$ & $\begin{array}{c}\text { K2 } \\
(400)\end{array}$ & Rata-Rata & $\begin{array}{c}\text { NP. BNT } \\
\alpha 0,01\end{array}$ \\
\hline G1 (Impago 7) & 11.79 & 13.37 & 14.31 & 13.15 & 1.34 \\
G2 (Impago 10) & 11.23 & 13.54 & 15.15 & 13.30 & 13.11 \\
G3 (Situ Bagendit) & 12.04 & 13.07 & 14.20 & 13.48 & \\
G4 (Varietas Lokal) & 12.62 & 13.33 & 14.50 & & \\
\hline Rata-Rata & $11.92^{\mathrm{a}}$ & $13.32^{\mathrm{b}}$ & $14.28^{\mathrm{b}}$ & &
\end{tabular}

Keterangan : Angka-angka yang diikuti oleh huruf yang tidak sama berarti berbeda nyata pada Uji BNT Taraf $\alpha 0,01$

Berdasarakan Tabel 6 menunjukan bahwa pemberian Biochar 200 gram/bedengan (K1) memberikan pengaruh lebih baik diduga karena pemberian Biochart dapat menambah unsur hara berupa unsur hara N, P dan $\mathrm{K}$ yang berkaitan dengan kebutuhan jumlah gabah isi dan bobot gabah yang terbentuk dalam satu malai, ini sangat tergantung dari proses fotosintesis dari tanaman selama pertumbuhannya. hasil dari fotosintesis yang tidak lain adalah fotosintat, sehingga naiknya fotosintat sama juga naiknya berat kering tanaman. Fotosintat yang lebih besar akan memungkinkan membentuk organ tanaman yang lebih besar kemudian menghasilkan produksi bahan kering yang semakin besar. Selain itu, banyaknya populasi juga memberikan ruang yang cukup sehingga sinar matahari dapat dimanfaatkan oleh tanaman padi secara merata untuk proses fotosintesis. Menurut Siregar dalam Evriani Mareza (2017) malai yang panjang memungkinkan tempat kedudukan gabah lebih banyak. Dengan demikian malai yang semakin panjang mempunyai peluang jumlah gabah per malai semakin banyak, dan 
produksi per satuan luas akan lebih tinggi. Namun bila jumlah gabah hampa per malai tinggi, maka produksi per satuan luas akan rendah.

\section{KESIMPULAN}

Hasil penelitian yang dilakukan dapat disimpulkan sebagai berikut :

1. Interaksi antara berbagai varietas padi gogo dengan Biochar kulit kakao tidak memberikan pengaruh nyata pada parameter tinggi tanaman umur 4 dan 8 MST, jumlah daun umur 4 dan 8 MST, jumlah anakan, hasil biomassa, berat 1000 bulir gabah dan Rata-Rata Produktivitas dalam ton/ha

2. Varietas Situ Bagendit (G3) memberikan pengaruh terbaik pada parameter tinggi tanaman umur 4 MST, begitu pula dengan Varietas lokal memberikan pengaruh baik pada parameter tinggi tanaman umur 8 MST.

3. Pemberian Biochar 400 gram/bedengan (K2) memberikan pengaruh baik pada parameter jumlah daun umur 4 dan 8 MST, jumlah anakan dan berat 1000 bulir gabah dan. Sedangkan dosis Biochar 200 gram/bedengan (K1) memberikan pengaruh terbaik pada parameter tinggi tanaman umur 4 MST, hasil biomassa dan Rata-Rata Produktivitas ton/Ha.

\section{UCAPAN TERIMA KASIH}

Ucapan terima kasih yang paling tulus dan penghargaan kepada Program Studi Agroteknologi Universitas Al Asyariah Mandar atas dukungan pada penelitian ini dan semoga penggunakan fasilitas penelitian tetap akan diberikan di masa yang akan datang.

\section{DAFTAR PUSTAKA}

Ade Alavan et al. 2015. Pengaruh Pemupukan terhadap Pertumbuhan Beberapa Varietas Padi Gogo (Oryza Sativa L.). J.Floratek 10:61-68.

BPS 2018. Badan Pusat Statistik.

Evriani Mareza, Ummi Kalsum, Yursida, Merry Wulandari. 2017. Pertumbuhan dan Produksi Padi (Oryza sativa L. pada Berbagai Sistem Tanam di Lahan Pasang Surut. ISBN : 978-979-587-748-6. Fakultas Pertanian Universitas IBA.

Ellya Ekaristi, 2013.Pertumbuhan Dan Produksi Beberapa Varietas Padi Gogo Terhadap Pemberian Pupuk Organik Cair. Jurnal Online Agroekoteknologi ISSN No. 2337- 6597 Vol.2, No.1: 113-120, Desember 2013. 
Haris Kriswantoro, Etty Safriyani, Syamsul Bahri. 2016. Pemberian pupuk organik dan pupuk npk pada tanaman jagung manis (zea mays saccharata sturt). KLOROFIL XI - $1: 1-$ 6. Fakultas Pertanian Universitas Palembang.

Herlina Fitri, 2009. Uji Adaptasi Beberapa Varietas Padi Ladang (Oryza sativa L). Skripsi Universitas Sumatera Utara. Medan.

James Manurung, Armaini dan Idwar. 2017. Uji Adaptasi Beberapa Varietas Padi Gogo (Oryza Sativa L.) Lokal dan Kondisi Tegangan Air Tanah yang Berbeda pada Bahan Tanah Ultisol.JOM FAPERTA VOL. 4 NO. 1. Fakultas Pertanian Universitas Riau.

Nyoman Hitakarana, 2017. Studi Stimulasi Pertumbuhan Kecambah Padi Sawah (Oryza sativa L.) Varietas Mekongga Dengan Ekstrak Air Daun Cemara Laut (Casuarina equisetifolial.). Skripsi Universitas Lampung. Bandar Lampung.

Nina Yunita Sari dkk, 2017.Respon Pertumbuhan Padi Gogo Lokal Yang Diberi Bahan Organik Pada Berbagai Kondisi Ketersediaan Air.e-J. Agrotekbis 5 (1) : 53 -57 ,ISSN : 2338-3011 Februari 2017.

N. L. Nurida, dkk, 2017. Pemanfaatan Biochar Kulit Buah Kakao Dan Sekam Padi Untuk Meningkatkan Produktivitas Padi Sawah Di Ultisol Lampung.

Ferdian Suete, Sakka Samudin, Uswah Hasanah. 2017. respon pertumbuhan padi gogo (oryza sativa) kultivar lokal pada berbagai tingkat kelengasan tanah. e-J. Agrotekbis 5 (2) : 173 - 182. Fakultas Pertanian. Universitas Tadulako. Palu.

Suci Rodian Noer, 2017.Analisis Efisiensi Produksi Usahatani Padi Ladang di Kecamatan Sidomulyo Kabupaten Lampung Selatan. Skripsi Universitas Lampung.

Suriansyah, dkk.2013. Pengelolaan Tanaman Terpadu (PTT) Padi Gogo.Badan Penelitian dan Pengembangan Pertanian Kalimantan Tengah.

Taufik Ramadhan, 2014. Pertumbuhan Dan Hasil Padi Ir-42 Pada Lahan Gambut Dengan Perlakuan Dosis Cu. Skiripsi Universitas Bengkulu.Kota Bengkulu. 